\title{
PENGARUH KONFLIK KERJA DAN STRES KERJA TERHADAP TURNOVER INTENTION PEGAWAI MADRASAH ALIYAH ASWAJ AMBUNTEN
}

\author{
Mohammad Rofik \\ Program Studi Manajemen, Universitas Wiraraja, Madura \\ rofik@wiraraja.ac.id
}

\begin{abstract}
This research was conducted to find out why employees perform Turnover Intention. This study was conducted on employees who work at Madrasah Aliyah Aswaj Ambunten Timur. Turnover Intention is defined as the intensity of employees who want to resign from a company or institution where they work. There are two independent variables in this study, namely work conflict and work stress. The data collection technique used a questionnaire with several indicators of independent and dependent variables. The sample in this study used a saturated sample where the total population was the same as the number of samples, namely 47 employees.
\end{abstract}

Keywords : Turnover Intention, Work conflict, Job stress

\begin{abstract}
ABSTRAK
Penelitian ini dilakukan untuk mengetahui sebab karyawan melakukan Turnover Intentention. Studi ini dilakukan pada karyawan yang bekerja di Madrasah Aliyah Aswaj Ambunten Timur. Turnover Intention diartikan sebagai intensitas karyawan yang ingin melakukan pengunduran diri dari sebuah perusahaan atau lembaga tempat bekerja. Terdapat dua variabel indepeneden dalam penelitian ini yaitu Konflik kerja dan Stres Kerja. Teknik Pengambilan data menggunakan kuisioner dengan beberapa indikator variabel Indenpenden dan Dependen. Sampel dalam penelitian ini menggunakan sampel jenuh dimana jumlah populasi sama dengan jumlah sampel yaitu sebanyak 47 karyawan.
\end{abstract}

Kata Kunci: Turnover Intention, konflik Kerja, Stres kerja

\section{PENDAHULUAN}

Sumber daya manusia (SDM) merupakan komponen paling penting dalam tatanan hidup, baik dalam bidang Sosial, Ekonomi serta Budaya. Sumber daya manusia menjadi satu - satunya penggerak segala aktifitas dimuka bumi ini, tidak ada manusia maka tidak akan berguna seluruh sumber daya alam yang ada di alam semesta ini.

Organiasi baik yang bersifat lembaga atau perusahaan pasti juga membutuhkan Sumber Daya Manusia untuk proses pengembangan ke depan demi mencapai visi dan misi organisasi tersebut, akan tetapi tak jarang karena Sumber Daya Manusia juga suatu organisasi bisa mengalami kekacauan. Proses perjalanan sebuah organisasi tidak akan pernah lepas dari permasalahan sumber daya manusia, salah satu permasalahan yang dihadapi suatu organisasi dalam sisi sumber daya manusia adalah keluar masukanya sumber daya manusia itu sendiri atau dalam bahasa manajemen SDM lebih dikenal dengan Turnover Intention. Ada dua hal yang menyebabkan sumber daya manusia keluar masuk dalam sebuah organisasi yaitu kurangnya kinerja sumber daya manusia itu sendiri sehingga membawa dampak negative bagi suatu organisasi dan organisasi itu sendiri yang tidak bisa mempertahankan sumber daya manusianya. Jika alasan organisasi mengeluarkan sumber daya manusia disebabkan karena kinerjanya tidak efektif maka barang tentu keputusan tersebut baik untuk organisasi akan tetapi jika sumber daya manusia melakukan turnover intention karena sesuatu hal yang berasal dari diri sendiri dan SDM tersebut mempunyai kualitas yang baik maka organisasi akan mengalami kerugian akibat perginya SDM tersebut. Sehingga menjadi perlu untuk sebuah organisasi belajar mempertahankan 
sumber daya manusia untuk tidak melakukan turnover intention.

Masalah turnover intention sebenanrnya tidak hanya terjadi pada perusahaan-perusahaan yang identic dengan profit oriented akan tetapi hal itu juga bisa terjadi pada lembaga-lembaga seperti pendidikan misalnya. Indonesia banyak dipenuhi dengan lembaga-lembaga pendidikan yang tidak di bawah naungan pemerintah sehingga segala sesuatu yang menjadi tanggung jawab lembaga sepenuhnya ditanggung oleh lembaga itu sendiri.

Madrasah Aliyah Ahlusunnah Waljamaah (MA ASWAJ) salah satu lembaga pendidikan yang terletak di Kecamatan ambunten Kabupaten Sumenep merupakan lembaga pendidikan yang mempunyai pegawai bukan pegawai negri sipil yang artinya segala kebutuhan operasional terkait pegawai sepenuhnya bergantung pada bantuan pemerintah. Hal semacam itu bisa memungkinkan terjadinya turnover Intention pada pegawai yang bekerja dilembaga tersebut. Jika hal itu terjadi maka lembaga tersebut harus melakukan rekrutment kembali untuk mengisi kekosongan posisi yang melakukan turnover. Sehingga sangat perlu bagi lembaga untuk memperhatikan penyebab seorang pegawai ingin melakukan turnover karena ketika itu terjadi maka yang terkena dampak jika itu merupakan lembaga pendidikan adalah peserta didik

Penyebab terjadinya turniver intention biasanya terjadi karena Konflik kerja diantara pegawai. Konflik kerja sebenarnya tidak akan pernah bisa dihindari dan pasti akan terjadi pada suatu organisasi namun demikian intenseitas pada konflik itu sendiri yang akan menyebabkan seorang pegawai tidak betah dilingkungan pekerjaannya, sehingga melakukan turnover atau resign. Selain itu penyebab terjadinya turnover intention adalah stres kerja, dimana stres kerja ini merupakan suatu kondisi seorang pegawai merasakn tekanan yang bertubi-tubi akibat adanya perintah dari atasan maupun beratnya tugas yang dia emban sehingga menyebabnyak pegawai itu stres dan tak tahan dengan pekerjaannya. Hal yang sedemikian itu harus menjadi perhatian husus bagi pengelola sebuah lembaga untuk meminimalisir gejalagejala tersebut.

Berdasarkan latar belakang di atas maka perlu dilakukan sebuah penelitian dengan Judul “ Pengaruh Konflik kerja dan Stres Kerja Terhadap Turnover Intention Pegawai Madasah Aliyah ASWAJ Ambunten.

\section{METODOLOGI PENELITIAN}

Jenis penelitian ini adalah jenis penelitian yang bersifat perhitungan yang kemudian di deskripsikan dengan fakta yang terjadi di lokasi pnelitian.

Lokasi penelitian ini dilakukan di Madrasah Aliyah ASWAJ Ambunten Timur Kabupaten Sumenep. Sedangkan waktu penelitian di lakukan pada bulan maret 2020 .

Jenis data yang digunakan dalam penelitian ini adalah data primer yang di ambil melalui kuisioner dengan menggunakan skala likert :

$\begin{array}{ll}\text { Sangat tidak setuju } & =1 \\ \text { Tidak setuju } & =2 \\ \text { Ragu }- \text { ragu } & =3 \\ \text { Setuju } & =4 \\ \text { Sangat setuju } & =5\end{array}$

\section{Variabel penelitian}

a. Variabel dependen (Y)

Variabel dependen adalah variabel yang nilainya dipengaruhi oleh variabel lain. Variable dependen dalam penelitian ini adalah Turnover Intention (Y).

b. Variabel Independen (X)

Variabel independen adalah variabel yang 
nilainya tidak dipengaruhi oleh variabel lain. Variabel independen dalam penelitian ini ada empat variabel adalah Konflilk Kerja (X1) dan Stres Kerja (X2),

\section{Definsi Operasional Variabel}

Definisi operasioanal Variabel menjelaskan tentan arti dari veriabel yang digunakan dalam penelitian sebagai berikut

1) Turnover Intention adalah keinginan seorang pegawai untuk pergi dari sebuah lembaga dimana tempat ia bekerja. Indikator - indikator yang digunakan untuk mengukur Turnover Intention adalah sebagi berikut:

a) Memikirkan untuk keluar (Thinking of Quitting): pegawai yang sudah memikirkan untuk keluar dari pekerjaannya. Hal ini bisa disebabkan oleh ketidak puasan terhadap pekerjaannya

b) Pencarian alternatif pekerjaan (Intention to search for alternatives): pegawai yang sudah memikirkan tempat kerja lain selain pekerjaannya saat ini, biasanya hal ini dilakukan dengan harapan jenjang karir yang lebih pasti dan lebih besar.

c) Niat untuk keluar (Intention to quit): mencerminkan seorang pegawai yang mempunyai niat untuk keluar dari tempat ia bekerja, bisa karena lingkungan kerja yang tidak memadai atau fasilitas yang kurang lengkap atau bahkan hal -hal lain yang menyebabkan seorang pegawai memutuskan untuk keluar dari pekerjaan.

2) Konflik Kerja adalah ketidaksesuaian diantara dua atau lebih anggota-anggota atau kelompok (dalam suatu organisasi/ perusahaan) yang harus membagi sumber daya yang terbatas atau kegiatankegiatan kerja dan atau karena kenyataan bahwa mereka mempunyai perbedaan status, tujuan, nilai, atau persepsi.

3) Stres Kerja adalah ketegangan yang dihadapi oleh pegawai saat tuntutan datang mengahampiri, ketegangan tersebut berubah menjadi sebuah tekanan yang berujung pada ketidak nyamanan dalam pekerjaan.

a) Stres Lingkungan

Ketidakpastian lingkungan mempengaruhi desain organisasi, sehingga ketidakpastian menjadi beban tersendiri bagi karyawan, terutama saat perubahan organisasi berlangsung. Dimensi lingkungan adalah ketidakpastian ekonomi, ketidakpastian teknologi dan ketidakpastian politik menyebabkan stres kerja karena karyawan merasa tenaganya tidak lagi dibutuhkan.

b) Stres Organisasi

Dimensi organisasi berkaitan dengan situasi dimana karyawan mengalami tuntutan tugas, tuntutan peran, tuntutan pribadi. Tuntutan tugas berkaitan dengan banyaknya pekerjaan yang harus diselesaikan membuat karyawan merasa kelelahan untuk menyelesaikan pekerjaannya. Tuntutan peran berkaitan dengan tekanan-tekanan yang dialami karyawan ketika menyelesaikan pekerjaannya. Tuntutan pribadi berkaitan kelompok kerja tidak memberikan bantuan teknis jika diperlukan.

c) Stres Individu

Dimensi ini mengenai kehidupan pribadi masing-masing karyawan. adalah masalah keluarga, masalah ekonomi pribadi dan kepribadian karyawan.

Sampel dalam penelitian ini adalah seluruh pegawai yang bekerja sebagai guru 
sekaligus staf di Madrasah Aliyah Aswaj Ambunten. Teknik pengambilan sampelnya menggunakan teknik pengambilan sampel jenuh yaitu dengan menjadikan seluruah anggota populasi untuk menjadi sampel.

\section{Teknik analisa data}

a. Uji Keabsahaan Data

1) Uji Validitas

Uji validitas adalah uji yang dilakukan terhadap hasil tabulasi jawaban responden. Uji validitas dilakukan untuk mengetahui apakah kuisioner yang diajukan kepada responden sudah bisa mengukur varibel bebas. Untuk mengetahui valid atau tidak dilihat nilai Corrected item total (Rhitung). Jika nila Rhitung > Rtabel maka dinyatakan Valid.

2) Uji Reliabilitas

Uji Realibilitas digunakan untuk menguji kehandalan atau konsistensi jawaban responden terhadap kuisioner. Uji validitas diuji menggunaka nilai Cronbach Alpha dengan ketentuan jika nilai Alpha > 0,60 maka dinyatakan Reliabel.

b. Uji Asumsi Kelasik

1) Uji Normalitas

2) Uji Multikolinieritas

3) Uji Autokorelasi

4) Uji Linieritas

5) Uji Heteroskedastisitas

c. Uji Regresi Linier Berganda

Analisis regresi linier berganda digunakan untuk menguji signifikan atau tidaknya hubungan variabel melalui koefisien regresinya:

$\mathrm{Y}=\mathrm{a}+\mathrm{b}_{1} \mathrm{X}_{1}+\mathrm{b}_{2} \mathrm{X}_{2}+\mathrm{e}$

Keterangan :

$\mathrm{Y}=$ Turnover Intention

$\mathrm{a}=$ Konstanta

$\mathrm{b}_{1234}=$ Koefisien Regresi

$\mathrm{X}_{1}=$ Konflik Kerja

$\mathrm{X}_{2}=$ Stres Kerja e = Tingkat kesalahan

1) Uji t

Uji t digunakan untuk mengetahui pengaruh parsial variabel independen terhadap variabel dependen dengan ketentuan jika nilai $t_{\text {hitung }}>\mathrm{t}_{\text {tabel }}$ maka $\mathrm{H} 0$ ditolak yang artinya terdapat pengaruh variabel Independen terhadap dependen

2) Uji F

Uji $F$ digunakan untuk mengetahui pengaruh secara simultas variabel independen terhadap dependen dengan ketentuan jika nilai $F_{\text {hitung }}>F_{\text {tabel }}$ maka H0 ditolak artinya terdapa pengaruh secara simultas Variabel Independen terhadap Variabel Dependen.

3) Uji Koefisien Determinasi

Uji ini dilakukan untuk mengukur seberapa jauh tingkat kemampuan model dalam menjelaskan dari variasi variabel dependen, nilai koefisien determinasi antara 0 dan 1. Dikatakan memiliki tingkat kemampuan terbatas jika nilai koefisien mendekati 0 . Namun dapat dikatakan memiliki tingkat kemampuan tidak terbatas (hampir keseluruhan) jika nilai koefisien 1.

\section{HASIL DAN PEMBAHASAN}

\section{Gambaran Umum Lokasi Penelitian}

MA Aswaj merupakan salah satu lembaga yang berada dibawah naungan yayasan Alhlussunnah Waljamaah, berlokasi di desa Ambunten Timur Kecamatan Ambunten. 


\section{Uji Kualitas Data}

\section{Validitas dan Reliabilitas}

Tabel Reliabilitas

\begin{tabular}{|c|c|c|c|}
\hline Variabel & Reliabilitas & $\begin{array}{c}\text { Cut Of } \\
\text { Value }\end{array}$ & Ket \\
\hline Y & 0,771 & 0,60 & Reliabel \\
\hline X1 & 0,724 & 0,60 & Reliabel \\
\hline X2 & 0,748 & 0,60 & Reliabel \\
\hline
\end{tabular}

Sumber : Hasil Olah data

Tabel Validitas

\begin{tabular}{|c|c|c|c|}
\hline Indikator & $\begin{array}{c}\mathbf{R} \\
\text { Hitung }\end{array}$ & $\begin{array}{c}\mathbf{R} \\
\text { Tabel }\end{array}$ & Ket \\
\hline Y1 & 0,552 & 0,2876 & Valid \\
\hline Y2 & 0,642 & 0,2876 & Valid \\
\hline Y3 & 0,624 & 0,2876 & Valid \\
\hline X11 & 0,311 & 0,2876 & Valid \\
\hline X12 & 0,656 & 0,2876 & Valid \\
\hline X13 & 0,573 & 0,2876 & Valid \\
\hline X14 & 0,534 & 0,2876 & Valid \\
\hline X21 & 0,616 & 0,2876 & Valid \\
\hline X22 & 0,561 & 0,2876 & Valid \\
\hline X23 & 0,560 & 0,2876 & Valid \\
\hline
\end{tabular}

Sumber : Hasil Olah data

Berdasarkan hasil uji keabsahan data di atas bisa ditarik kesimpulan bahwa indikator yang digunakan untuk mengukur variabel independen maupun dependen sudah dinyatakan valid dan reliabel.

\section{Uji Asumsi Klasik}

Uji Asumsi klasik adalah uji yang harus dipenuhi untuk menguji regresi linier berganda. Uji normalitas data mendapatkan nilai signifikan $0,200>0,05$ setelah membuang outliet dari beberapa responden yang berarti bahwa data yang digunakan berdistribusi normal. Kemudian uji multikolinieritas data mendapatkan nilai VIF yang sudah berada diantara 1-10 sedangkan unji autokorelasi sebesar 1,9 berarti berada diantara nlai du dan 4-du sedangkan untuk linier dan heteroskedastisitas juga tidak ada malsah, sehingga pengujian regresi linier berganda bisa dilanjutkan.

\section{Uji Regresi Linier Berganda}

Uji regresi linier berganda digunakan untuk mengetahui pengaruh variabel independen terhadap dependen. Estyimasi dalam penelitian ini adalah sebagai berikut:

$\mathrm{Y}=\mathrm{a}+\mathrm{b} 1 \mathrm{X} 1+\mathrm{b} 2 \mathrm{X} 2+\mathrm{ei}$

Persamaan diatas dapat dijelaskan oleh tabelhasil olah data dibawah ini:

\begin{tabular}{|c|l|c|c|}
\hline \multicolumn{4}{|c|}{ Coefficients $^{\text {a }}$} \\
\hline $\begin{array}{c}\text { Mode } \\
1\end{array}$ & & $\begin{array}{l}\text { Unstandardize } \\
\text { d Coefficients }\end{array}$ & \\
\hline & & B & Std. Error \\
\hline 1 & (Constant) & 3,411 & 1,366 \\
\hline & $\begin{array}{l}\text { KONFLIKKERJ } \\
\text { A }\end{array}$ & 0,109 & 0,054 \\
\hline & STRESKERJA & 0,631 & 0,098 \\
\hline
\end{tabular}

Sumber : Hasil Olah Data

$\mathrm{Y}=3,422+0,109 \mathrm{X} 1+0,631 \mathrm{X} 2+\mathrm{ei}$

a: adalah konstanta 3,422 yang berart bahwa ketika X1 dan X2 sama dengan 0 maka $\mathrm{Y}=\mathrm{a}$ b1 : 0,109 adalah koefisien regresi yang mana ketika ada kenaikan variabel konflik kerja satu satuan maka akan menaika variabel Y sebesar b1

b2 : 0,631 adalah koefisien regresi yang mana ketika ada kenaikan variabel stres kerja satu satuan maka akan menaika variabel $\mathrm{Y}$ sebesar b1

\section{Uji Partial (uji t)}

Uji $t$ digunakan untuk mengetahui pengaruh secra partial variabel independen terhadap dependen. Uji $\mathrm{t}$ dapat diliat pada tabel berikut:

\begin{tabular}{|c|c|r|r|}
\hline \multicolumn{3}{|c|}{ Coefficients $^{\text {a }}$} \\
\hline \multicolumn{2}{|c|}{ Model } & $\mathrm{t}$ & Sig. \\
\hline 1 & (Constant) & 2,497 & 0,016 \\
\hline \multicolumn{2}{|c|}{ KONFLIKKERJA } & 2,025 & 0,049 \\
\hline \multicolumn{2}{|c|}{ STRESKERJA } & 6,458 & 0,000 \\
\hline
\end{tabular}

Sumber : Hasil Olah data SPSS

Berdasarkan tabel diatas dapat disimpulkan bahwa terdapat pengaruh konflik kerja terhadap Turnover Intention pada pegawai MA ASWAJ. Hal ini dibuktikan dengan nilai signifikan $0,049<0,05$ sehingga 
hipotesis 0 ditolak. Semakin tinggi konflik kerja makan akan semakin tinggi pula intesitas karyawan melakukan resign. Strees kerja juga memiliki nilai signifikan yang lebih kecil dari 0,05 sehingga bisa disimpulkan bahwa stres kerja juga berpengaruh postif serta signifikan terhadap turnover intention, dimana ketika stres kerja meningkat akan meningkat turnover intention pada pegawai MA Aswaj.

\section{Uji Simultaan (Uji F)}

Uji $F$ digunakan untuk megetahui pengaruh secara bersama-sama variabel independen terhadap dependen. Uji $\mathrm{F}$ dapat dilihat dari tabel dibawah ini:

\begin{tabular}{|c|r|r|r|c|c|}
\hline \multicolumn{7}{|c|}{ ANOVA $^{\text {a }}$} \\
\hline Model & $\begin{array}{c}\text { Sum of } \\
\text { Squares }\end{array}$ & df & $\begin{array}{c}\text { Mean } \\
\text { Square }\end{array}$ & F & Sig. \\
\hline Regression & 46,476 & 2 & 23,238 & 29,381 & $.000^{\mathrm{b}}$ \\
\hline Residual & 34,800 & 44 & 0,791 & & \\
\hline Total & 81,277 & 46 & & & \\
\hline
\end{tabular}

Sumber: hasil olah data spss

Berdasarkan tabel Anova diatas dapat kita lihat bahwa nilai sig. 0,000 $<0,05$ yang berarti bahwa terdapat pengaruh secara simultan Konflik kerja dan stres kerja terhadap turnover intention pegawai MA Aswaj Ambunten.

\section{Uji Koefisien determainasi $\mathbf{R}^{2}$}

Uji koefisien determinasi digunakan untuk mengetahui besaran persentase pengaruh variabel independen terhadap variabel dependen. Besaran nilai $\mathrm{R}^{2}$ dapat kita lihat pada tabel dibawah ini:

\begin{tabular}{ll|r|r|}
\multicolumn{3}{c}{ Model Summary $^{\mathbf{b}}$} \\
Model & R & R Square & Adjusted \\
R Square
\end{tabular}

Sumber : hasil olah data SPSS

Berdasarkan tabel diatas nilai koefisien determinasi sebesar 0,552 yang berarti bahwa pengaruh variabel konflik kerja dan stres kerja sebanyak 55,2\% terhadap variabel tuenover intention. Sedangak $44,8 \%$ dipeengaruhi oleh variabel lain yang tidak diteliti dalampenelitian ini.

\section{KESIMPULAN}

Berdasarkan hasil penelitian dan pembahasan diatas maka peneliti akan menarik simpulan yang terkait dengan penelitiannya sebagai berikut :

a. Konflik kerja berpengaruh postif dan signifikan terhadap turnover pegawai MA Aswaj Ambunten

b. Stres kerja berpengaruh positif dan signifikan terhadap turover intention pegawai MA Aswaj Ambunt

\section{DAFTAR PUSTAKA}

Halimah, T., Fathoni, A., \& Minarsih, M. (2016). Pengaruh Job Insecurity, Kepuasan Kerja dan Lingkungan Kerja terhadap Turnover Intention Pramuniaga di Galael Supermarket (Studi Kasus pada Galael Superindo Kota Semarang). Journal of Management, 2(2), 1-16.

Hartanto, A. P., \& Rahardja, E. (2016). Analisis Pengaruh Kedisiplinan, Gaya Kepemimpinan, dan Motivasi Terhadap Kinerja Karyawan (Studi pada Perusahaan Otobus Jaya Indah Semarang). Diponegoro Journal of Management, 5(1), 1-12.

Mauladi, F., \& Dihan, F. N. (2015). Pengaruh Stres Kerja pada Kinerja dengan Kecerdasan Emosional sebagai Variabel Moderasi (Studi pada Karyawan Rumah Sakit Condong Catur Yogyakarta). Jurnal Bisnis Dan Ekonomi, Vol 6(No.2), 51-62.

Muttaqin, L. Z. (2016). Pengaruh Gaya Kepemimpinan Transformasional dan Pengembangan SDM terhadap Kinerja Perawat RSJ Grhasia Yogyakarta. Revista Brasileira de Ergonomia, 9(2), 
10.

https://www.infodesign.org.br/infodesig n/article/view/355\%0Ahttp://www.aberg o.org.br/revista/index.php/ae/article/view /731\%0Ahttp://www.abergo.org.br/revist a/index.php/ae/article/view/269\%0Ahttp: //www.abergo.org.br/revista/index.php/a e/article/view/106

Novita, Sunuharjo, B. S., \& Ruhana, I. (2016). Pengaruh Kepuasan Kerja dan Komitmen Organisasional Terhadap Kinerja Karyawan. Jurnal Administrasi Bisnis (JAB), 34(1), 38-46.

Susilo, J., \& Satrya, I. G. B. H. (2019). Pengaruh Kepuasan Kerja Terhadap Turnover Intention Yang Dimediasi Oleh Komitmen Organisasional Karyawan Kontrak. E-Jurnal Manajemen Universitas Udayana, 8(6), 3700. https://doi.org/10.24843/ejmunud.201 9.v08.i06.p15Amanah, Dita, 2010. pengaruh harga dan kualitas produk terhadap kepuasan konsumen pada majestyk bakery \& cake shop cabang h.m. yamin medan. Jurnal Keuangan dan bisnis. Vol. 2 No. 1.

Horax, M, Sanjaya, L, Pratiwi, J, Yosephien, A, K,. 2017. Analisis Kepuasan Konsumen terhadap Pelayanan Restoran Cepat Saji (Restoran X) dengan Metode Service Quality (Servqual). Jurnal metris 18. ISSN.

Sugiono. 2009. Memahami Pernelitian Kualitatif. Alfabeta, Bandung.

Sugiono. 2011. Metodelogi Penelitian Kuantitatif, Kualitatif, R \&D. Alfabeta, Bandung. 